doi:10.1017/S1474745618000319

\title{
Russia - Anti-Dumping Duties on Light Commercial Vehicles from Germany (Russia-Commercial Vehicles) (DS479)
}

\author{
Adopted \\ 9 April 2018 \\ Complainant \\ European Union \\ Respondent \\ Russian Federation \\ Third Parties \\ Brazil, China, India, Japan, Korea, Turkey, \\ Ukraine, and US \\ Third Participants \\ Brazil, China, Japan, Korea, Turkey, Ukraine, \\ and US
}

\section{Measure at Issue and Background}

The dispute relates to anti-dumping duties imposed by Russia on certain light commercial vehicles (LCVs) from Germany and Italy. These anti-dumping duties were applied pursuant to Decision No. 113 of 14 May 2013 of the Board of the Eurasian Economic Commission (EEC), including the relevant annexes, notices, and reports of the Department for Internal Market Defence of the EEC (DIMD). ${ }^{1}$

Before the panel, the European Union (EU) requested findings of inconsistency with Articles 3.1, 3.2, 3.4, 3.5, 4.1, 6.5, 6.5.1, and 6.9 of the Anti-Dumping Agreement. The EU also brought claims under Articles 1 and 18.4 of the Anti-Dumping Agreement and Article VI of the GATT 1994 as a consequence of the previously mentioned breaches. Both Russia and the EU appealed the panel report. Russia appealed the panel's findings under Articles 3.1, 3.2, 4.1, 6.5, and 6.9 of the Anti-Dumping Agreement as well as Articles 15.2 and 7 of the Understanding on Rules and Procedures Governing the Settlement of Disputes (DSU). For its part, the EU appealed the panel's findings in respect of Articles 3.1, 3.2, 3.4, and 6.9 of the Anti-Dumping Agreement and also made claims pursuant to Article 17.6 of the Anti-Dumping Agreement and Article 11 of the DSU.

\section{Main Adopted Findings of the Panel and the Appellate Body}

\section{Articles 3.1 and 4.1 of the Anti-Dumping Agreement}

The EU claimed that the DIMD's definition of 'domestic industry' was inconsistent with Articles 3.1 and 4.1 of the Anti-Dumping Agreement. According to the EU, the DIMD failed to conduct an objective examination based on positive evidence, because it defined the domestic industry as a single producer (Sollers) that accounted 
for $87.8 \%$ of total domestic production of the like product during the period of investigation (POI) and excluded another company (GAZ) from that definition. Excluding GAZ from the definition of 'domestic industry' led to a risk of materially distorting the injury analysis. ${ }^{2}$

The panel found that DIMD erred in its definition of 'domestic industry' because: First, it decided not to include a known producer of the like product after having reviewed that producer's data, which gave an appearance that it selected domestic producers based on their data to ensure a particular outcome. This resulted in a risk of material distortion. Second, the reasons for the exclusion were not provided in the Investigation Report and thus constituted impermissible ex post explanations. ${ }^{3}$ Third, even if the reasons were provided in the report, they were not reasons that a reasonable and unbiased investigating authority could rely upon in deciding not to include a producer in the definition of 'domestic industry'. Particularly, when the exclusion was based on the difficulty the investigating authority faced in distinguishing between confidential and non-confidential information in the questionnaire response. ${ }^{4}$ The panel concluded that the DIMD acted inconsistently with Article 4.1 as it made injury and causation determinations based on information related to an improperly defined 'domestic industry'. Consequently, the DIMD acted inconsistently with Article 3.1.5

On appeal, Russia challenged the panel's findings. ${ }^{6}$ The Appellate Body found that the panel did not err in its interpretation and application of Articles 3.1 and 4.1 of the Anti-Dumping Agreement and thus upheld the panel's findings. According to the Appellate Body, if an investigating authority were permitted to exclude from the definition of 'domestic industry' producers of the like product on the basis of allegedly deficient information, a material risk of distortion would arise from the injury analysis. This exclusion of that producer or producers would render the definition of 'domestic industry' no longer representative of the total domestic production. Article 3.1 does not allow for this type of conduct from the investigating authority. Article 6 establishes tools that the authorities may use to address inaccurate or incomplete information. ${ }^{7}$

\section{Articles 3.1 and 3.2 of the Anti-Dumping Agreement}

Moreover, the EU argued, based on the non-confidential published report, that the DIMD failed to consider certain injury factors enumerated under Article 3.4, namely, return on investments, actual and potential effects on cash flow, and the ability to raise capital or investments. ${ }^{8}$ The EU appealed and the Appellate Body reversed the

2 Ibid. para. 7.4 .

3 Russia explained that the DIMD did not intentionally exclude GAZ at the beginning. GAZ was excluded because it submitted deficient questionnaire responses; thus the DIMD continued the investigation with respect to Sollers only. Ibid. para. 7.6.

4 Ibid, para. 7.15.

5 Ibid. para. 7.16

6 Ibid. para. 5.1.

7 Appellate Body Report, Russia-Commercial Vehicles, paras. 5.40-5.41.

8 Panel Report, Russia-Commercial Vehicles, para. 7.163. 
panel's findings. According to the Appellate Body, the panel improperly relied on the confidential investigation report without determining whether that document formed part of the investigating record when the determination to impose the anti-dumping measure was made. In fact, Russia only submitted this version of investigation report with its first written submission to the panel. Therefore, the EU could not have been aware of its contents before that date. ${ }^{9}$ The Appellate Body also declined to complete the panel's analysis. ${ }^{10}$

The EU had also argued that the DIMD improperly disregarded the inventories of a dealer related to Sollers (the domestic company). The panel rejected the EU's claims and ruled, inter alia, that there was no indication that the car dealer's inventories were an economic factor relevant to the state of the domestic LCV-producing industry. ${ }^{11}$ The Appellate Body agreed with the panel. Evidence concerning a related dealer may be pertinent to the evaluation of the relevant economic factor having a bearing on the state of the domestic industry. However, this should be assessed on a case-by-case basis and the proximity of the relationship between the related entities is not dispositive. ${ }^{12}$

The EU claimed that the DIMD acted inconsistently with Articles 3.1 and 3.2 by failing to make an objective examination of the price-suppressive effect of the dumped imports based on positive evidence. Specifically, the EU argued that: (i) the DIMD constructed the estimated prices that would have occurred in the absence of dumping by using the abnormally high reported profit rate of 2009 as the benchmark without further adjustments; (ii) the DIMD failed to properly consider the trends of imports and domestic prices in an objective manner by confusing data expressed in Russian roubles (RUS) and United States' dollars (USD); (iii) the DIMD failed to conduct its analysis based on positive evidence because it did not examine the relationship between import and domestic price trends, reasons for Sollers' cost increases, and the impact of competition from GAZ; and (iv) the DIMD did not provide a reasoned and adequate explanation as to why the alleged price suppression was 'to a significant degree'. ${ }^{13}$

The panel: (i) found that the DIMD acted inconsistently with Articles 3.1 and 3.2 because it failed to consider the financial crisis in determining the appropriate rate of return; (ii) rejected the claim that the DIMD mixed up data expressed in USD and RUB without any explanation; (iii) rejected the claim against the DIMD's analysis of whether the imports at issue have 'explanatory force' for the price suppression of domestic prices. The panel found that the record evidence was not sufficient to require DIMD to consider whether the market would absorb price increases beyond those that took place in its consideration of price suppression; ${ }^{14}$ and (iv) rejected the claim that the DIMD failed to demonstrate that the alleged price suppression was to a 'significant degree' because it did not compare the estimated and actual prices. ${ }^{15}$

9 Appellate Body Report, Russia-Commercial Vehicles, para. 5.144.

10 Ibid. para. 5.145.

11 Panel Report, Russia-Commercial Vehicles, para. 7.123.

12 Ibid. paras. 5.165-5.167.

13 Panel Report, Russia-Commercial Vehicles, para. 7.54.

14 Ibid. para. 7.91.

15 Ibid. para. 7.108 . 
Both the EU and Russia appealed various aspects of panel's findings. Regarding Russia's appeal, the Appellate Body agreed with the panel that the DIMD failed to take account of the impact of the financial crisis in determining the rate of return for its price suppression determination. ${ }^{16}$ The Appellate Body explained that consideration of evidence regarding the financial crisis would not call into question whether the 'explanatory force' of dumped imports for price suppression would lead to a biased analysis, because there might be other factors that could also affect the selected rate of return. ${ }^{17}$ The Appellate Body thus upheld the panel's findings. ${ }^{18}$

The Appellate Body confirmed the EU's claim under Article 11 of the DSU. The Appellate Body considered that the panel's findings concerning the long-term price trends and degree of significant price suppression are incoherent and inconsistent with its previous finding that the DIMD acted in a WTO-inconsistent manner by using the 2009 rate of return to determine the domestic target price. ${ }^{19}$ The Appellate Body thus reversed the panel's finding.

\section{Articles 6.5, 6.5.1, and 6.9 of the Anti-Dumping Agreement}

The EU claimed that the DIMD improperly treated certain information as confidential under Articles 6.5 and 6.5.1 because: (i) the DIMD failed to require a showing of good cause for the confidential treatment; (ii) the DIMD did not assess whether the good cause shown was sufficient to warrant the confidential treatment; (iii) there was no meaningful summary of the submitted confidential information; nor (iv) was an explanation provided as to why a summary was not possible. ${ }^{20}$ In respect of Article 6.9, the EU alleged that the DIMD did not disclose certain essential facts regarding all aspects of the decision to apply the definitive measure, i.e., the existence of dumping and the determination of material injury caused by the dumped products. ${ }^{21}$

The panel found that Russia did not identify any instance of good cause by the submitter of the information based on which the DIMD extended the confidential treatment. Russia agreed that many of the documents do not contain an express allegation or showing of good cause. ${ }^{22}$ Thus, the panel found that DIMD acted inconsistently with Article 6.5.23

The Panel accepted the EU's claim under Article 6.9, and both Russia and the EU appealed. The Appellate Body found that the panel erred when it found that treating essential facts improperly as confidential automatically leads to an inconsistency with Article 6.9. However, the Appellate Body completed the analysis and found that the DIMD acted inconsistently with Article 6.9 by failing to disclose most of the essential

\footnotetext{
16 Appellate Body Report, Russia-Commercial Vehicles, para. 5.64.

17 Ibid. para. 5.59 .

18 Ibid. para. 5.110.

19 Ibid. paras. 5.82, 5.84 .

20 Panel Report, Russia-Commercial Vehicles, para. 7.238.

21 Ibid. para. 7.250.

22 Ibid. para. 7.242 .

23 Ibid. para. 7.247.
} 
facts at issue. ${ }^{24}$ The Appellate Body found another error, in that the panel improperly found that sources of information do not constitute essential facts.

Kholofelo Kugler Works in the Advisory Centre on WTO Law (ACWL), but writes in a personal capacity Email: Kholofelo.Kugler@acwl.ch

doi:10.1017/S1474745618000320

\section{European Communities and Certain Member States - Measures Affecting Trade in Large Civil Aircraft (EC and Certain Member States-Large Civil Aircraft) (DS316)}

\author{
Adopted \\ Complainant \\ Respondent \\ Third Parties/ \\ Participants
}

\author{
28 May 2018 \\ United States \\ European Union, France, Germany, Spain, \\ United Kingdom \\ Australia, Brazil, Canada, China, Japan, and \\ Korea
}

\section{Measures at Issue, Background, and Request for Findings}

This dispute relates to the compliance proceedings in which the panel and the Appellate Body found that that European Union (EU) and certain of the member States acted inconsistently with their obligations under the Agreement on Subsidies and Countervailing Measures (SCM Agreement). The types of measures at issue in the original panel proceedings include the Launch Aid/Member State Financing (LA/MSF) for, inter alia, the A300, A310, and A380; French and German government 'equity infusions' provided in connection with the corporate restructuring of Aérospatiale and Deutsche Airbus; certain infrastructure and related measures provided by the German and Spanish authorities; and research and technological development funding provided by the European Communities and certain member States. ${ }^{1}$ The EU replaced the terminated the A300 and A310 programmes with new LA/MSF programmes, including the A350XWB LA/MSF subsidies. ${ }^{2}$

24 The weighted average export prices of LCVs respectively produced by Daimler AG and Volkswagen AG. Ibid. paras. 5.203-5.208.

1 Panel Report, EC and Certain Member States - Large Civil Aircraft, paras. 7.290(a)(i)-(vii), 7.482-7.496, 7.1049-7.1053, 7.1097, 7.1100-7.1101, 7.1134, 7.1137-7.1139, 7.1191, 7.1205-7.1211, 7.1244, 7.12457.1249, 7.1302, 7.1323-7.1326, 7.1380-7.1384, 7.1414, 7.1427-7.1456, 7.1459-1480, 7.1608, 8.1(a)(i), 8.1 (b)(i)-(iv), 8.1(c) and (d), and 8.1(e).

2 Ibid. paras. 6.54 and 6.55 . 